International Journal of English Literature and Social Sciences
Vol-6, Issue-2; Mar-Apr, 2021

\title{
Improve, Expand and Strengthen State-owned Capital to Enhance International Competitiveness of Chinese
}

\section{Enterprises}

\author{
Ran Wei \\ Central University of Finance and Economics, School of Economics, China
}

Received: 22 Dec 2020; Received in revised form: 12 Feb 2021; Accepted: 03 Mar 2021; Available online: 18 Mar 2021 (C2021 The Author(s). Published by Infogain Publication. This is an open access article under the CC BY license (https://creativecommons.org/licenses/by/4.0/).

\begin{abstract}
Since 1978, China has been carrying out the reform and opening-up policy for nearly 40 years, this 40 years is also be the 40 years that economic globalization develops ceaselessly all over the world. Under the dual influence of national policy guidance and international background, the internationalization of Chinese enterprises has also achieved rapid development. Yet Chinese firms still have plenty of problems. This requires scientific planning of the future direction of enterprise development. It is of great significance to China's future economic development. This paper analyzes the internationalization process of Chinese enterprises, the development of Chinese enterprises. This paper specifically analyzes several prominent problems that Chinese enterprises are facing at present, as well as the internal causes of these problems. Finally, the corresponding policy suggestions are given.
\end{abstract}

Keywords- Enterprise reform, Internationalization, Innovation.

\section{BASIC SITUATION OF CHINESE}

\section{ENTERPRISES IN THE WORLD}

(1) The Development Course of Chinese Enterprises' Internationalization

Recently, in General Secretary Xi Jinping's report on the 19th CPC National Congress, the need to deepen the reform of state-owned enterprises, develop a mixed ownership economy and foster world-class enterprises with global competitiveness were once again stressed. This fully embodies that the Party Central Committee, with Comrade Xi Jinping as its core, attaches great importance to the reform and development of state-owned enterprises.

State-owned enterprises, in international practice only refers to enterprises invested or be involved in controlling

ISSN: 2456-7620

https://dx.doi.org/10.22161/ijels.62.14 by a country's central government or federal government. In China, State-owned enterprises also include enterprises that are invested and controlled by local governments. Internationalization usually has two meanings. One is inward internationalization, which is commonly referred to as "inviting in". It mainly refers to import and purchase patented technology and introduce of foreign capital, etc.; The other is outward internationalization, or "going global", which mainly refers to enterprises' export, technology transfer and outward foreign direct investment. China's internationalization can be divided into four stages:

First, the tentative stage: 1979-1991. In 1979, the State Council promulgated 15 reform measures, clearly 
stipulating that enterprises can be set up abroad, and the internationalization of Chinese enterprises then began from this. During this period, China's internationalization is mainly inward-oriented, to absorb foreign capital, with finding a way for future development. This stage is in line with the first stage described in Den Ning's investment development stage theory.

Second, the initial stage: 1992-2001. When Deng Xiaoping made his southern tour in 1992, he put forward the development strategy of "bringing in", which made up for the shortage of domestic resources, broadened the international market and introduced advanced technology. This stage is in line with the second stage described in the theory of investment development stage. The state's foreign capital attraction ability is obviously increased, with the large inflow of foreign capital, but the export of foreign capital is very limited.

Third, the strengthening stage: 2002-2013. In 1998, Jiang Zemin put forward the policy of "going global" in Shanghai, and it was incorporated in to "The Tenth Five-Year Plan" in 2001. Since then, "bringing in, going global" has become a national policy that China always adheres to in promoting China's export-oriented economic development. This is exactly a reflection of the basic situation of the third phase proposed by Deng Ning, the country's outward investment has increased significantly, but the net outward direct investment still remains negative.

Fourth, the high-speed development stage: 2014 to date. In recent years, under the environment of the proposal and implementation of "the Belt and Road Strategy", and the active promotion of international production capacity cooperation and other policies, foreign trade has achieved a higher level of development, providing more opportunities for the internationalization of domestic enterprises. The year 2014 was a turning point, for the first time, China's outward investment exceeded foreign investment in China, and sustained rapid growth, so that China has gradually transformed from a big receiving country of overseas direct investment into a big country of foreign investment. In 2016, China's outward direct investment reached a historic breakthrough, with the investment exceeding one trillion yuan for the first time. According to 2017 World Investment Report released by the United Nations Conference on Trade and Development, China has become the world's second-largest foreign investor for the first time, This is basically in line with the elaboration of the fourth stage, the country net foreign direct investment is positive, enterprises begin to have stronger ownership advantage and internalization advantage, and has the ability to discover and use foreign location advantage.

(2)Status Quo of Internationalization development of Chinese Enterprises

According to data from Fortune China 2013 to 2017 Fortune Global Top 500 Ranking List, in the past five years, the number of Chinese enterprises entering the world's top 500 has also been increasing, becoming the second largest country after the United States and with a big lead over the third place Japan. Since 2013, 95 enterprises have been listed in the top 500, and about 5 enterprises have been increased every year, and there were 115 by 2017 , second only to the United States and with a great tendency to surpass. Some scholars estimate that in the next three to five years, China's enterprises entering into the world's top 500 are expected to surpass the United States.

According to Fortune China 2017 Fortune Global Top 500 Ranking List, there are 53 trillion-dollar companies worldwide, with 22 in the United States, 5 in Japan, 4 in Germany, 3 in France, 2 in the UK and the Netherlands, 1 in Switzerland and 1 in South Korea, with a total of 40. The other 13 trillion-dollar companies are all from China, with 4 banks, 2 insurance companies, 1 telecom company, 3 energy companies, 1 auto company, 1 ICT company and 1 Chinese construction company.

Statistics on operating income and profits of countries in 2017 Top 500 Ranking List show that it is not just the number of Chinese enterprises on the list is increasing, but the quality of their operations is steadily improving. By 2017, the average operating income of Chinese enterprises was nearly $\$ 55$ billion, higher than that of the UK and Japan; the average profit was nearly $\$ 3$ billion, second only to that of the US. Compared with the significant decline in operating income of most countries, China is 
basically stable.

According to Fortune China 2017 Fortune Global Top 500 Ranking List, among the top 500 companies in the world, State Grid, Sinopec and ICBC all rank first in the industry in the world, and State Grid and Sinopec rank second and third respectively in the top 500. While leading the world in the field of energy and banking sectors, private enterprises and the Internet are also on the rise, and the new economy and service enterprises are increasing significantly. Some scholars estimate that by 2030 more outstanding enterprises will emerge from industries such as health care, big culture, tourism, new energy, new finance and smart manufacturing. (As shown in Table 1)

Table 1 Statistics on the specific conditions of each industry

\begin{tabular}{|c|c|c|c|}
\hline Company name & Industry & 2017 ranking & Operating income (US \$100 million) \\
\hline $\begin{array}{c}\text { State Grid Corporation of } \\
\text { China }\end{array}$ & Public utility & 2 & 3151.99 \\
\hline $\begin{array}{l}\text { Sinopec (China Petroleum } \\
\text { and Chemical Corporation) }\end{array}$ & Oil refining & 3 & 2675.18 \\
\hline $\begin{array}{c}\text { Industrial and Commercial } \\
\text { Bank of China }\end{array}$ & Commercial bank & 22 & 1476.75 \\
\hline China State Construction & $\begin{array}{c}\text { Engineering and } \\
\text { Architecture }\end{array}$ & 24 & 1445.05 \\
\hline Huawei & $\begin{array}{c}\text { Network and } \\
\text { communication } \\
\text { equipment }\end{array}$ & 83 & 785.11 \\
\hline China Resources & $\begin{array}{l}\text { Pharmaceutical } \\
\text { industry }\end{array}$ & 86 & 757.76 \\
\hline Minmetals Group & Metal product & 120 & 655.47 \\
\hline
\end{tabular}

Data source: Fortune China 2017 Fortune World Top 500 Ranking List

However, due to the intensification of the international market competition, the complexity of the external environment and the different development process of enterprises internationalization, the development of enterprises internationalization still faces many challenges.

\section{PROBLEMS EXISTING IN INTERNATIONALIZATION DEVELOPMENT OF CHINESE ENTERPRISES}

Chinese Enterprises Are Big but Not Strong. At present, Chinese enterprises are flourishing in transnational trade and foreign projects, and China are known as the world factory because of the large number, wide range and large scale of Chinese enterprises. But the problem now is that although China is a big manufacturing country, it cannot be called a powerful manufacturing country ${ }^{[1]}$. Although
China is a big trading country, it is not a powerful trading country. The internationalization progress of our country is rapid, but still cannot get rid of the fact that the enterprise is big not strong.

\section{Low Technology Content, at the Low End of the Value}

Chain. Nowadays, most of the enterprises in China are at the low end of the value chain division on foreign projects. The main reasons are lack of core technology, low added value of products and lack of market competitiveness. With the rapid development of science and technology, the manufacturing industry in some developed countries have stepped into the era of "industry 4.0", while some areas in China are still moving from "industry 2.0" to "industry 3.0". Facing the competitive pressure of high-tech and high-value-added of foreign brands, some enterprises in our country can only engage in low-value-added manufacturing links. for example, "IPhone", it is sold 
more than 200 million phones a year, but Chinese enterprises in the manufacturing segment get only $\$ 6.5$ per phone in the value chain.

Relying on Cheap Labor and Natural Resources. Although China's energy enterprises are huge, Chinese international enterprises in heavy industry are mainly concentrated in the field of primary resource exploitation, mainly taking the advantage of cheap labor resources and natural resources as the main source of competitive advantage. Due to the low technology capability, the internationalization process of Chinese enterprises is often limited. Once the resources become scarce or the policy adjustment of host country is met, the labor force and raw materials become expensive, the advantage of Chinese enterprises in this aspect will be lost. Therefore, due to the complex and changeable environment at home and abroad, some energy enterprises in our country will not survive and continue simply by mastering cheap labor and raw materials, and enterprises will be expelled from the market finally. The lower technical capacity composition also makes it difficult to effectively adapt to the market environment of developed countries.

Chinese Enterprises Are Big but Not Superior. Great achievements have been made in China's economic development, but the quality problems in our country are very common. Food safety problems, "cheap copy" phenomenon and other quality problems have caused a very bad impact on China's brand products. At the same time, the lack of quality integrity and the low price sales mode in our country have caused foreign consumers to form a negative preconceived impression of the quality of Chinese enterprises' products and services. Compared with "Made in Germany" and "Made in Japan", the consumers' cognition of "Made in China" is still limited to "Cheap" and "Mass Production". It has become difficult to open high-end markets abroad and create a first-line group.

Chinese Enterprises Lack of Independent Brands. After the reform and opening-up, Chinese enterprises, on the one hand, bear the domestic market impact brought by international brands, on the other hand, in order to adapt to the international market and go abroad, Chinese enterprises have made a lot of adjustments and efforts, by virtue of our own manufacturing capacity and scale advantages to overcome a lot of difficulties, a batch of multinational companies have emerged. But as a whole, although there are many Chinese enterprises going abroad, there is still a lack of first-line brand group with international influence, which leads to the manufacturing capability and scale advantage of our country cannot be translated into the brand advantage of Chinese enterprises.At the same time, the lack of humanistic care and not very good marketing ability make it difficult for China to display its brand value even if China produces high-quality products. The development of Chinese manufacturing scale does not match with the development of brand, the current number of well-known brands makes it difficult to shape the image of "Made in China" as a brand power. Nowadays, the shortage of independent brands has become the main "short board" that restricts the transformation and upgrading of Chinese manufacturing industry. Huawei is the only one Chinese brand in the top 100 global brands released by Interbrand as of 2014. Huawei and Lenovo are the only two Chinese companies in the top 100 in 2017. China urgently needs to realize the all-round expansion of enterprise brand from point to line and from line to surface.

Chinese Enterprises Are Big but Not Innovative. Science and technology change life and innovation makes the future. Through the mastery of high technology, accelerate the transformation and development of enterprises to reach the monopoly position in the advanced field, which has become the new thinking of the future of enterprises. In the field of quantum communication, big data and cloud computing, our country has some development and breakthrough, but the degree is far from enough, and there are still shortcomings in some sophisticated technology, for example: semiconductor processing and manufacturing is basically occupied by Japan and the United States; Ultra-high precision machine tool technology is also monopolized by Japan and Germany; Industrial robot is the global industry that will develop vigorously in the next 50 years, and currently the technology is basically in the hands of Japan; In the engineering equipment ranking list, China did not make 
the top 10. All these show that although we are innovating, we still lag a lot.

Lack of Technology in the Future of Chinese

Enterprises. China has launched a decade-long "Made in China 2025" plan, aimed to realize efficient and reliable intelligent manufacturing by using advanced manufacturing technologies such as robots, 3D printing and the industrial Internet. At the same time, China has launched another national plan, "the Internet Plus", it seeks to combine the mobile Internet, cloud computing, big data and the Internet of Things with modern manufacturing. But we know that the United States and Japan are now vigorously developing Internet of Things, industrial robots, big data cloud computing, from the advanced patent application, we can see that the patent of big data analysis is currently basically monopolized by IBM and Microsoft of the United States, and Hitachi, NTT, and Fujitsu of Japan. The technology and patents of the Internet of Things are also being divided by the United States and Japan. At present, nearly half of Japanese enterprises have started to apply the technology of the Internet of Things. Industrial robots have always been Japanese domain, and most of China's robots are not produced at home, and even some are assembled domestically, they still heavily dependent on importing core components from abroad.

\section{ANALYSIS OF THE REASONS FOR THE \\ LACK OF INTERNATIONAL COMPETITIVENESS OF CHINESE \\ ENTERPRISES}

There Are Defects in Independent Innovation Mechanism of State-owned Enterprises. From the analysis of the current situation, we can see that most of the enterprises participating in international competition are state-owned enterprises. Because of their large scale and relatively concentrated resources, they are usually able to compete with international multinational corporations in terms of volume. But we also found that these enterprises win based on the capital volume, the net profit of only a few enterprises can surpass the developed countries. Moreover, there is a certain gap with other countries in such core competitive forces as technology level, service quality and innovation ability. Dong Xiaohua et al. have measured the innovation efficiency of state-owned enterprises and found that the innovation efficiency of state-owned enterprises is significantly lower than that of private enterprises, and they believe that rent-seeking is the main reason ${ }^{[2]}$. This paper mainly analyzes the reasons for the low innovation efficiency and lack of competitiveness from the perspective of the system mechanism of state-owned enterprises.

First, the obvious administrative characteristics of the appointment and removal of enterprises leaders make enterprises lack independent development business decision-making ability. For state-owned enterprises, senior leaders are appointed through government the approval of government department. However, leaders usually appointed by the government have tenure, which makes their business decisions often less long-term, even if there is sustainability, there will be conflicts between their business decisions as a result of turnover, and then the decisions will not be well implemented. Moreover, the leaders who are usually appointed or removed by the government do not have a thorough understanding of the industry in which state-owned enterprises are located, and their business decisions are usually conservative.

Second, the government and enterprises cannot really separate and lack fault-tolerant mechanism. On the one hand, in the process of state-owned enterprises reform, whether state-owned or mixed ownership, the government will still on behalf of the state and intervene and control the enterprise in the form of "sole share" and "dominant share", which leads the state-owned enterprises to be unable to free themselves from competition in the market, and at the same time, it also affects the government's function of managing the state and regulating the economy, resulting in the contradiction between the enterprise property right subject and the internal requirements of the market economy. On the other hand, the most need for the reform and innovation of state-owned enterprises is trial and error, however, the current system mechanism that still has administrative characteristic makes the manager take too much account of administrative responsibility instead of paying attention to innovation and development with 
great risks, so there will be some bad phenomenon such as "to stay away from innovation and development when there is any chance, not to do innovation and development when there is any chance, to postpone innovation and development when there is any chance".

The Innovation Incentive Mechanism is Not Perfect. First, the intellectual property rights protection system is not perfect, and the enterprise innovation lacks safeguard. Although China has issued laws and regulations on intellectual property rights, for example, in March 2017, the Anti-monopoly Bureau of the Ministry of Commerce issued a draft soliciting opinions on Guidelines on Anti-monopoly Regulation on Abuse of Intellectual Property Rights, which indicates that China is speeding up its progress in this respect, but it has not really been realized. From the current situation, the current policy system coordination is not enough. The coordination between innovation policy and science and technology policy and economic policy is not enough.

Second, the combination degree of production, education and research is insufficient, and the ability of scientific research transformation is poor. In the case of small and medium-sized enterprises gradually participating in the global competition, the cost of independent investment in scientific research of small and medium-sized enterprises is usually large, and the combination of production, education and research is not deep enough, which makes small and medium-sized enterprises excessively rely on foreign technology and model in international competition. Universities and research institutes often connect with large enterprises and can't connect with small and medium-sized enterprises in depth, which is also the place where research and real economy are disconnected.

\section{CONCLUSION AND SUGGESTIONS}

\section{Intensify In-depth Reform to state-owned Enterprises.}

To enhance the international competitiveness of Chinese enterprises, we must improve and strengthen the core competitiveness of state-owned enterprises. First, the mixed ownership reform of state-owned enterprises should be strengthened. According to the research of Wang Yewen etc., the mixed ownership reform of state-owned enterprises has significantly enhanced the innovation ability and efficiency of state-owned enterprises ${ }^{[3]}$. Improve personnel appointment and removal system, and performance incentive system; Second, cultivate multi-level management talents to enhance the execution of business decisions; Third, strengthen the introduction and training of innovative talents, self-owned research and development personnel, and enhance the ability of scientific research conversion; The fourth is to emphasize the separation of government and enterprise, increase the fault-tolerant mechanism, give enterprises full freedom of the right to make decisions, and enhance the vitality of enterprises.

\section{Strengthen the Construction of Innovation Incentive}

System. First, set up a multi-level intellectual property protection system, speed up the distribution of overseas intellectual property rights, and strengthen the support for innovative enterprises. Second, need to give precise support to enterprise. For state-owned enterprises, the incentive to their independent innovation should be increased, strengthen the subsidies for the combination of production, education and research, and promote their efficiency. Studies show that government subsidies improve the innovation supply of enterprises and have a greater promoting effect on the innovation supply of invention patents, state-owned enterprises and capital and technology-intensive enterprises, however, the control power of state-owned enterprises weakens the promoting effect of government subsidies on the innovation supply of enterprises ${ }^{[4]}$. Therefore, it is necessary to strengthen government subsidies degree for innovation while giving enterprises full freedom to operate their businesses.

\section{REFERENCES}

[1] Xiongyuan, Wang, Shan, Wang, School, \& of, et al. (2013). Chairman's government background, excess employment and government subsidies: evidence from chinese local state-owned enterprises. China Journal of Accounting Research, 01(No.342), 53-76.

[2] Li, M. , Lien, J. W. , \& Zheng, J. . (2018). Optimal subsidies in the competition between private and state-owned enterprises. International Review of 
Economics \& Finance.

[3] Putnins, T. . (2015). Economics of state-owned enterprises. Published Paper Series, 38(11), 1-18.

[4] Rickard, \& Stephanie, J. . (2018). Spending to win (political institutions, economic geography, and government subsidies) $\|$ the policy effects of electoral competitiveness in closed-list pr. 10.1017/9781108381475(7), 170-198 